\title{
Human umbilical cord blood stem cells applied in therapy for ionizing radiation injury
}

\author{
Xinwen Zhang, Yujun Xia* and Chenglong JI \\ Department of Anatomy, Qingdao University Medical College, Qingdao 266071, People's Republic of China
}

\begin{abstract}
Since the events of ionizing radiation damage increasingly, the human healthy are threatened by radiation. With the development of cells regeneration, stem cells applied in therapy for radiation injury become a hotspot in recent years. Then we are aimed to study on experimental animals to human umbilical cord blood stem cells of ionizing radiation-induced hematopoietic injury. The 80 mice were randomly divided into normal group, radiation group, treatment group, strengthen group. Beside normal group, other groups were given 1 hour of $1 \mathrm{~Gy}$ radiation. Radiation group does not do any processing after radiation while treatment groups and strengthen group were given the stem cells by tail vein of mice (230IU/g dose). After $24 \mathrm{~h}$ the strengthen group was given the stem cells again. All mice were sacrificed in $2 \mathrm{~d}, 3 \mathrm{~d}, 7 \mathrm{~d}, 14 \mathrm{~d}$ for blood routine examination and flow cytometry. The radiation group, treatment group, strength group that their white blood cells, red blood cells, lymphocytes, mononuclear cells, hemoglobin count dropped significantly after $1 \mathrm{~Gy}$ radiation. Compared with normal group that there were significant differences $(\mathrm{p}<0.05)$. The treatment group and strength group that their white blood cells, red blood cells, lymphocytes, monocytes and hemoglobin counts were significantly higher than radiation group and normal group and showed significant differences $(\mathrm{p}<0.05)$. Compared with normal group, the radiation group, treatment group and strength group that their CD4+ cells, CD4+/CD8+ cells ratio significantly higher after radiation, the differences were significant (p<0.05). After the injection of stem cells from human umbilical cord blood, the treatment group and strength group CD4+ cells, CD4+/CD8+ cells ratio significantly lower than normal group, there were significant differences $(\mathrm{p}<0.05)$. This study indicates that human umbilical cord blood stem cells contribute to the recovery of hematopoietic system after irradiation injury.
\end{abstract}

\section{Introduction}

Long-term ionizing radiation or cancer patients receive radiation therapy are often accompanied by severe immunosuppression and other diseases. The effects of ionizing radiation on hematopoietic system has been become a hot topic in recent years. Nowadays, the major treatment is the drug that consists of cytokines, hormones, herbal medicine and Chinese herbal medicine. With the long development cycle of chemical drugs that most have toxic side effects. To finding an effective and low-toxicity treatments of radiation injury medical become a problem. Therefore, we are intended to human umbilical cord blood stem cells in repairing radiation damage in preliminary discussions for further research, rational development and utilization of the theory.

\section{Materials and methods}

\section{Drug}

The drug tested was composed of Human umbilical cord blood stem cells purchased from Tsinghua University Shenzhen Institute.

\section{Rats}

All procedures described in the study were reviewed and approved by the Ethical Committee of Qingdao University. ICR, a widely used experimental strain, male, clean grade, weight $(20 \pm 2)$ g, were provided by Qingdao Food and Drug Administration.

\section{Grouping}

Eighty ICR rats were divided into four groups randomly: normal Group (not for radiation and the stem cell injection), the radiation group (simple radiation) and the treatment group (radiation plus stem cell injection), and strengthen group (radiation, and stem cell injection two times). Each groups were divided into four subgroups: 2, 3, 7, and 14 days.

\section{Establishment of rat radiation damage model}

The radiation group, treatment group and strengthen group were send to the Hospital Centre for $1 \mathrm{~Gy}$ dose of ionizing radiation. The stem cells were equal distribution after $1 \mathrm{~h}$ radiation, then via tail vein of rats to the treatment group and strengthen group. The normal group and radiation group were without any remedy. After that, send all groups of rats to animal house with a regular feeding. The strengthen group was given tail intravenous injection of stem cells again at the second day.

Execute method in rats by intraperitoneal injection of chloral 0.5 $\mathrm{ml}$, drugged and placed on the dashboard fixed and open the abdomen and thorax to exposing the heart, we took blood from heart about 300 $\mu \mathrm{l}$. Then put the $300 \mu \mathrm{l}$ divide into $100 \mu \mathrm{l}$ and $200 \mu \mathrm{l}$ to different EDTA anti-coagulated tubes. The $100 \mu \mathrm{l}$ of anticoagulant tube was send to Qingdao City hospital laboratory for blood routine examination. The $200 \mu \mathrm{l}$ blood was send to the Central Hospital of Qingdao bio-

Correspondence to: Yujun Xia, Department of Anatomy, Qingdao University Medical College, Qingdao 266071, People's Republic of China, Tel: +8613863976458;E-mail: Xiayujun62@163.com

Keywords: human umbilical cord blood stem cell, radiation, hematopoietic function, flow cytometry

Received: June 28, 2015; Accepted: July 28, 2015; Published: August 03, 2015 
Therapy Center for flow cytometry T-lymphocyte subsets CD4+, CD8+ cell values change, apply the appropriate data processing program respectively and each specimen testing on 10,000 cells used by United States Bectom/Dickinson FACSsan .

\section{Statistical analysis}

All statistical analysis was performed using SPSS 11.55. All data were carried out using independent samples t-test and one-way ANOVA, with $\alpha=0.01$ as test standards. $\mathrm{P}<0.05$ was considered statistically significant.

\section{Results}

\section{Blood test results}

The radiation group, treatment group, strengthen group that their white blood cells, red blood cells, lymphocytes, mononuclear cells, hemoglobin count dropped significantly after $1 \mathrm{~Gy}$ radiation (Figure 1). Compared with normal group that there were significant differences $(\mathrm{F}=4.67 \sim 33.24, \mathrm{q}=3.37 \sim 13.56, \mathrm{p}<0.05)$. The treatment group and strengthen group that their white blood cells, red blood cells,

White blood cells detection in different groups at different times

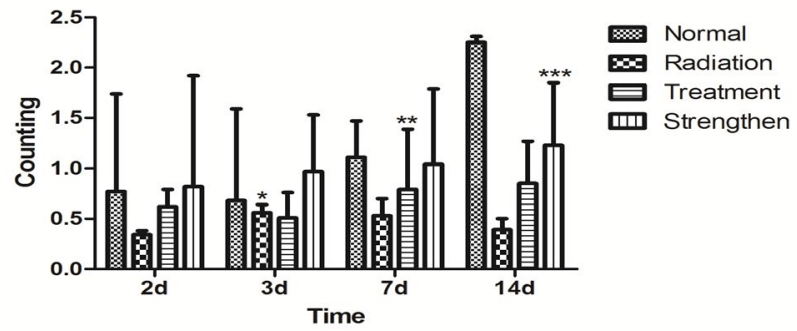

Figure 1a. Compared with the normal group, $* * * \mathrm{p}<0.01$; compared with the radiation group, ${ }^{* *} \mathrm{p}<0.05$; compared with the treatment group, $\# \mathrm{p}<0.05$.

Lymphocyte detection in different groups at different times

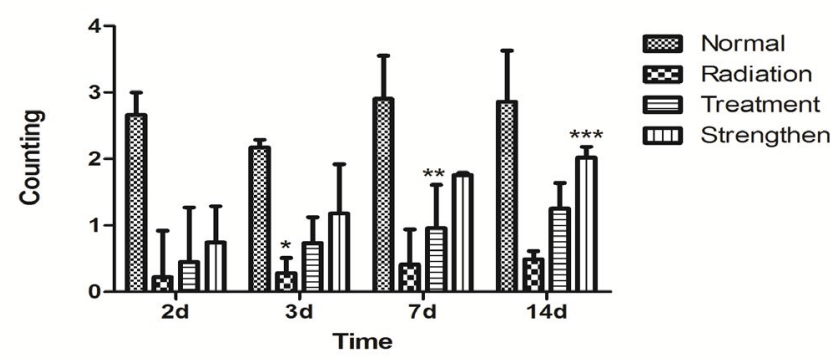

Figure 1b. Compared with the normal group, ${ }^{* * *} \mathrm{p}<0.01$; compared with the radiation group, ${ }^{* *} \mathrm{p}<0.05$; compared with the treatment group, $\# \mathrm{p}<0.05$.

Red blood cells detection in different groups at different times

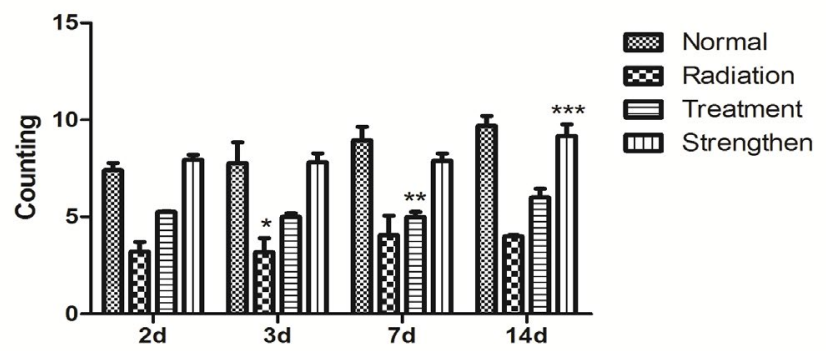

Figure 1c. Compared with the normal group, ${ }^{* * *} \mathrm{p}<0.01$; compared with the radiation group, ${ }^{* *} \mathrm{p}<0.05$; compared with the treatment group, $\# \mathrm{p}<0.05$.

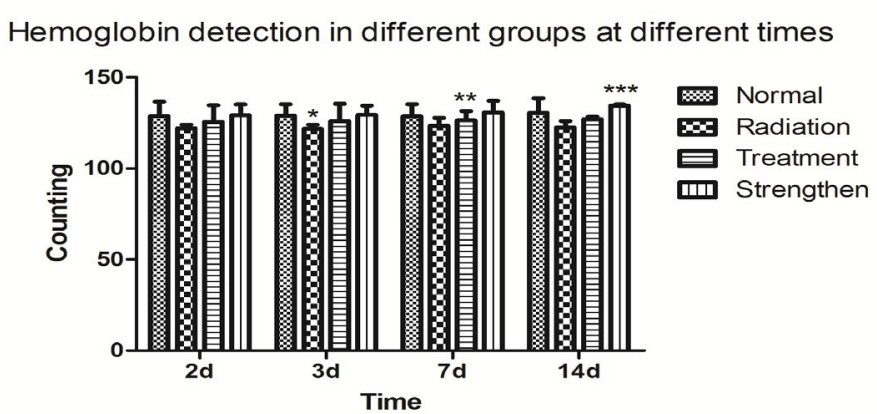

Figure 1d. Compared with the normal group, ${ }^{* * *} \mathrm{p}<0.01$; compared with the radiation group, ${ }^{* *} \mathrm{p}<0.05$; compared with the treatment group, $\# \mathrm{p}<0.05$.

\section{Monocytes detection in different groups at different times}

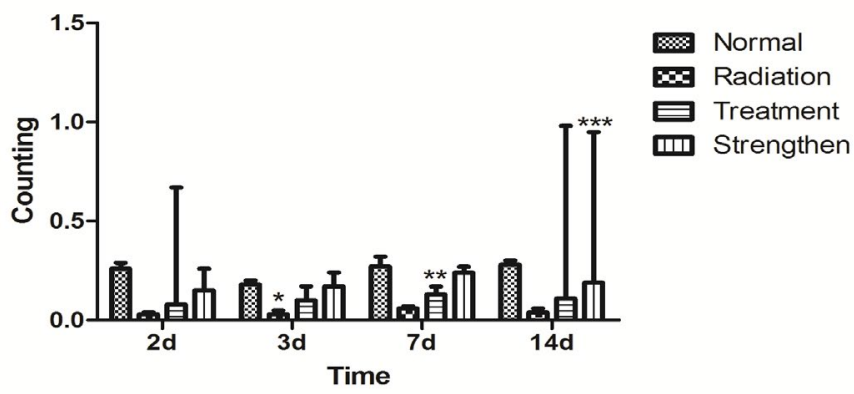

Figure 1e. Compared with the normal group, ${ }^{* * *} \mathrm{p}<0.01$; compared with the radiation group, ${ }^{* *} \mathrm{p}<0.05$; compared with the treatment group, $\# \mathrm{p}<0.05$.

CD4+ cells detection in different groups at different times

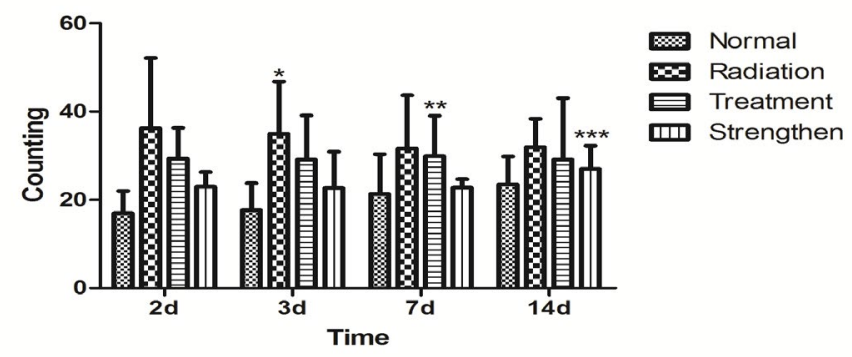

Figure 2a. Compared with the normal group, $* * * \mathrm{p}<0.01$; compared with the radiation group, ${ }^{* *} \mathrm{p}<0.05$; compared with the treatment group, $\# \mathrm{p}<0.05$.

lymphocytes, monocytes, and hemoglobin counts were significantly higher than radiation group and normal group and showed significant differences $(\mathrm{F}=22.19 \sim 31.22, \mathrm{q}=3.69 \sim 7.55, \mathrm{p}<0.05)$. The white blood cells, red blood cells, lymphocytes, monocytes and hemoglobin count in the treatment group were lower than in the strength group. The difference was significant $(\mathrm{F}=17.65 \sim 29.93, \mathrm{q}=4.05 \sim 8.11, \mathrm{p}<0.05)$.

\section{Flow cytometry results}

Compared with normal group, the radiation group, treatment group and strengthen group that their CD4+ cells, CD4+/CD8+ cells ratio significantly higher after radiation, the differences were significant $(\mathrm{F}=19.96 \sim 25.45, \mathrm{q}=3.03 \sim 4.95, \mathrm{p}<0.05)$. After the injection of stem cells from human umbilical cord blood, the treatment group and strengthen group CD4+ cells, CD4+/CD8+ cells ratio significantly lower than normal group, there were significant differences $(\mathrm{F}=5.53 \sim$ $11.64, \mathrm{q}=4.03 \sim 9.50, \mathrm{p}<0.05)$. In comparison with the radiation group, 


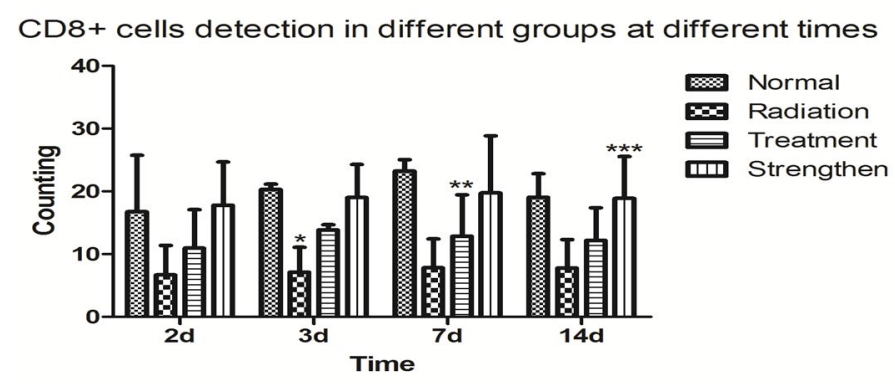

Figure 2b. Compared with the normal group, ${ }^{* * *} \mathrm{p}<0.01$; compared with the radiation group, ${ }^{* *} \mathrm{p}<0.05$; compared with the treatment group, $\# \mathrm{p}<0.05$.

\section{CD4+/CD8+ cells detection in different groups at different times}

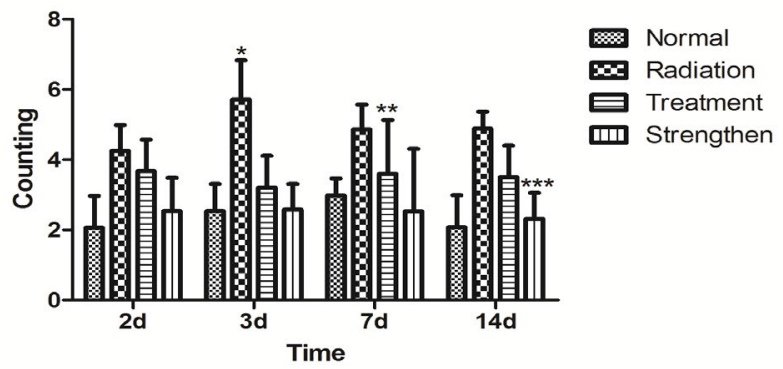

Figure 2c. Compared with the normal group, ${ }^{* * *} \mathrm{p}<0.01$; compared with the radiation group, ${ }^{* *} \mathrm{p}<0.05$; compared with the treatment group, $\# \mathrm{p}<0.05$.

after the injection of stem cells from human umbilical cord blood, the sum total of $\mathrm{CD} 4+$ cells and the ratio of $\mathrm{CD} 4+/ \mathrm{CD} 8+$ cells were decreased in strength. The same result was found in the treatment group. The difference was significant $(\mathrm{F}=5.53 \sim 11.64, \mathrm{q}=4.03 \sim 9.50$, $\mathrm{p}<0.05)$. The sum total of $\mathrm{CD} 4+$ cells and the ratio of $\mathrm{CD} 4+/ \mathrm{CD} 8+$ were decreased in strengthen group than in the treatment group. The difference was significant $(\mathrm{F}=7.99 \sim 17.25, \mathrm{q}=3.19 \sim 7.87, \mathrm{p}<0.05)$.

Stem cells in mice after radiation injury effect of white blood cells

The radiation group, treatment group, strengthen group that their white blood cells count dropped significantly after $1 \mathrm{~Gy}$ radiation. The treatment group and strengthen group that their white blood cells counts were significantly higher than radiation group and normal group. The white blood cells counts in the treatment group were lower than in the strength group.

\section{Stem cells in mice after radiation injury effect of lymphocyte}

The radiation group, treatment group, strengthen group that their lymphocyte count dropped significantly after $1 G y$ radiation. The treatment group and strengthen group that their lymphocyte counts were significantly higher than radiation group and normal group. The lymphocyte counts in the treatment group were lower than in the strength group.

\section{Stem cells in mice after radiation injury effect of red blood} cells

The radiation group, treatment group, strengthen group that their red blood cells count dropped significantly after 1Gy radiation. The treatment group and strengthen group that their red blood cells counts were significantly higher than radiation group and normal group. The red blood cells counts in the treatment group were lower than in the strength group.

\section{Stem cells in mice after radiation injury effect of hemoglobin}

The radiation group, treatment group, strengthen group that their hemoglobin count dropped significantly after $1 \mathrm{~Gy}$ radiation. The treatment group and strengthen group that their hemoglobin counts were significantly higher than radiation group and normal group. The hemoglobin counts in the treatment group were lower than in the strength group.

\section{Stem cells in mice after radiation injury effects of monocytes}

The radiation group, treatment group, strengthen group that their monocytes count dropped significantly after $1 \mathrm{~Gy}$ radiation. The treatment group and strengthen group that their monocytes counts were significantly higher than radiation group and normal group. The monocytes counts in the treatment group were lower than in the strength group.

\section{Stem cells in mice after radiation injury effect of lymphocyte subsets CD4+ cells}

Compared with normal group, the radiation group, treatment group and strengthen group that their CD4+ cells significantly higher after radiation. After the injection of stem cells from human umbilical cord blood, the treatment group and strengthen group CD4+ cells significantly lower than normal group. In comparison with the radiation group, after the injection of stem cells from human umbilical cord blood, the sum total of CD4+ cells were decreased in strength. The same result was found in the treatment group. The sum total of CD4+ cells were decreased in strengthen group than in the treatment group.

Stem cells in mice after radiation injury effect of lymphocyte subsets CD8+ cells

Compared with normal group, the radiation group, treatment group and strengthen group that their CD8+ cells significantly lower after radiation. After the injection of stem cells from human umbilical cord blood, the treatment group and strengthen group CD8+ cells significantly higher than normal group. In comparison with the radiation group, after the injection of stem cells from human umbilical cord blood, the sum total of CD8+ cells were increased in strength. The same result was found in the treatment group. The sum total of CD8+ cells were increased in strengthen group than in the treatment group.

Stem cells in mice after radiation injury effect of ratio of lymphocyte subsets CD4+/CD8+ cells

Compared with normal group, the radiation group, treatment group and strengthen group that their $\mathrm{CD} 4+/ \mathrm{CD} 8+$ cells ratio significantly higher after radiation. After the injection of stem cells from human umbilical cord blood, the treatment group and strengthen group $\mathrm{CD} 4+/ \mathrm{CD} 8+$ cells ratio significantly lower than normal group. In comparison with the radiation group, after the injection of stem cells from human umbilical cord blood, the ratio of CD4+/CD8+ cells were decreased in strength. The same result was found in the treatment group. The ratio of $\mathrm{CD} 4+/ \mathrm{CD} 8+$ were decreased in strengthen group than in the treatment group.

\section{Discussion}

The radiation on cell damage mainly through the direct and indirect effects of causing acute radiation injuries of ionizing radiation, that 
may directly kill cells, are also available through chemical reactions of free radicals cause long-term radiation. And sometimes may produce a series of biological effects on the body that causing radiation damage. Such as human hematopoietic system, immune system, nervous system and reproductive system damage or irreversible lesions likes cancer [1].

The hematopoietic systems are damaged by Ionizing radiation, mainly for inhibition of hematopoiesis function. Radiation protect are play a due role in normal tissue cells based on the maximum kill tumor cells. Anderson [2] was the first to report injuries of ionizing radiation induced hematopoietic systems, specialists in the later study, found that ionizing radiation can cause $\mathrm{T}$-cells and $\mathrm{B}$-cells reduction rapidly, while the lymphocytes are involved in hematopoietic regulation. Stem cells are survived in the hematopoietic microenvironment, valueadded, differentiated hematopoietic role played. T lymphocytes are the major components in microenvironment. Both the T lymphocytes and B lymphocytes are coadjutant in the body's activities. Based on our research, this experiment of simulated clinical radiation applied in therapy radiation damage models via stem cells in tail vein stem to observe the different stages of peripheral blood lymphocyte subsets in rats CD4+ cells, CD8+ cells and effect of blood routine examination. To get the further research on radiation to hematopoietic, and study on stem cells in radiation damage and protect efficacy [3]. The function of CD4 molecules can as cell adhesion molecules as well as a signaling molecule and prompting the activation of T-cells. CD8 cells have the effect of cytoadherence and signal function. The capability of $\mathrm{T}$ cells may affected by expression of CD4, CD8 [4], and affecting the entire blood system eventually.

Azzam et al. [5] through the establishment of radiation damage model in the study of mesenchymal stem cells in the treatment of radiation damage not only found the ionizing radiation to haemopoietic immune system intervention and effects of protective ionizing radiation, but also reports that imbalance between oxygen-derived free radicals in the body caused by radiation. In addition, LiMin Luo in human umbilical cord blood mesenchymal stem cells against radiation damage effects of treatment, use $\gamma$-rays to whole body irradiation of rats and infusion the human umbilical cord blood mesenchymal stem cells to rats by the tail veil. Then use the flow cytometry and immune cell apoptosis index parameters. Found that NK cells, CD4+, CD8+ markers was significantly changed and umbilical cord blood mesenchymal stem cells activity were significantly improves compared with irradiation group. A large number of reports, ionizing radiation can accelerate cellular aging and pose an obstacle to the hematopoietic system. Stem cells are pluripotent cells with self-replicating ability that can differentiate into a variety of functional cells in some conditions [6].

To sum up, ionizing radiation can cause the damage on hematopoietic system in rats. However, the number of immune cells in rats can changed after intravenous injection of stem cells. In addition, it can increase the proportion of cells in the peripheral blood and relieved the damage radiation on hematopoietic system. Therefore, the stem cells have the repair function in the body after ionizing radiation damage. The stem cells are a kind of self-renewal, highly value-added and multilineage differentiation potential cells, while its wide range of clinical applications making stem cells become the hot pints. The development and utilization of stem cell resistance to ionizing radiation damage remains to be further explored. This study we explore the basis of stem cell Foundation to its mechanism and provide reference for subsequent research [7].

\section{References}

1. Saha S, Woodbine L, Haines J, Coster $\mathrm{M}$, Ricket $\mathrm{N}$, et al. (2014) Increased apoptosis and DNA double-strand breaks in the embryonic mouse brain in response to very low-dose X-rays but not $50 \mathrm{~Hz}$ magnetic fields. J R Soc Interface 11: 20140783. [Crossref]

2. Kadhim M, Salomaa S, Wright E, Hildebrandt G, Belyakov OV, et al. (2013) Nontargeted effects of ionizing radiation-implications for low dose risk. Mutat Res 752 84-98. [Crossref]

3. Charles Sinclair, Iren Bains, Andrew J. Yates, Benedict Seddon (2013) Asymmetric thymocyte death underlies the CD4: CD8 T-cell ratio in the adaptive immune system. Proc Natl Acad Sci U S A 110: E2905-E2914. [Crossref]

4. Hernández-Hoyos G, Anderson MK, Wang C, Rothenberg EV, Alberola-Ila J (2003) GATA-3 expression is controlled by TCR signals and regulates CD4/CD8 differentiation. Immunity 19: 83-94. [Crossref]

5. Azzam EL, Jay-Gerin JP, Pain D (2012) Ionizing radiation-induced metabolic oxidative stress and prolonged cell injury. Cancer Lett 327: 48-60. [Crossref]

6. Pollard JM, Reboucas JS, Durazo A, Kos I, Fike F, et al. Radio-protective effects of manganese-containing superoxide dismutase mimics on ataxia telangiectasia cells. Free Radic Biol Med 47: 250-260. [Crossref]

7. Henríquez-Hernández LA, Carmona-Vigo R, Pinar B, Bordón E, Lloret M, et al. (2011) Combined low initial DNA damage and high radiation-induced apoptosis confers clinical resistance to long-term toxicity in breast cancer patients treated with high-dose radiotherapy. Radiat Oncol 6-60. [Crossref]

8. Hei TK, Zhou H, Chai Y, Ponnaiya B, Ivanov VN (2011) Radiation Induced Nontargeted Response: Mechanism and Potential Clinical Implications. Curr Mol Pharmacol 4: 96-105. [Crossref]

9. Baker JE, Moulder JE, Hopewell JW (2011) Radiation as a Risk Factor for Cardiovascular Disease. Antioxid Redox Signal 15: 1945-1956. [Crossref]

10. Schettino G, Al-Rashid ST, Prise KM(2010) Radiation microbeams as spatial and temporal probes of subcellular and tissue response. Mutat Res 704: 68-77. [Crossref]

11. Kuncic, Byrne HL, McNamara LA, Guatelli S (2012) In Silico Nanodosimetry: New Insights into Nontargeted Biological Responses to Radiation. Comput Math Methods Med 2012: 147252 .

12. Min Li, Géraldine G, Buonanno M, Autsavapromporn N, de Toledo SM, et al. (2014) Health Risks of Space Exploration: Targeted and Nontargeted Oxidative Injury by High-Charge and High-Energy Particles. Antioxid Redox Signal 20: 1501-1523. [Crossref]

Copyright: (C2015 Zhang X. This is an open-access article distributed under the terms of the Creative Commons Attribution License, which permits unrestricted use, distribution, and reproduction in any medium, provided the original author and source are credited. 